\title{
Nitrogen application rate and timing management for improved grain quality parameters of wheat crop
}

\author{
Gul Roz Khan ${ }^{1}$ and Mohammad Akma ${ }^{2, *}$ \\ ${ }^{1}$ Department of Agronomy, The University of Agriculture Peshawar 25120 Peshawar Pakistan; ${ }^{2}$ Department of Agronomy, \\ The University of Agriculture Peshawar, 25120 Peshawar Pakistan \\ *Corresponding author's e-mail: akmal@aup.edu.pk
}

\begin{abstract}
Nitrogen use efficiency under flood irrigation system is generally low (30\%) in field crops, which is one of the fundamental factors of high production cost in the developing countries. Optimum rate and timing of $\mathrm{N}$-application is otherwise important to harvest good quality grain for backing in the recent climate change scenario. Optimum N-rate (NAR) corresponds with the application timing (NAT) has resulted in good quality grains. Aim of the study was to focus on spring wheat grain quality and $\mathrm{N}$ use efficiency (NUE) with NAR (i.e., $0,100,120,140$ and $160 \mathrm{~kg} \mathrm{ha}^{-1}$ ) and NAT (i.e., $100 \%$ at sowing $\left(\mathrm{NAR}_{1}\right), 50 \%$ at sowing and $50 \%$ at tillering ( $\mathrm{NAT}_{2}$ ), $25 \%$ at sowing, $50 \%$ at tillering and $25 \%$ at booting $\left(\mathrm{NAT}_{3}\right.$ ) and $25 \%$ at sowing, $25 \%$ at tillering and $50 \%$ at booting $\left.\left(\mathrm{NAT}_{4}\right)\right\}$. Treatment impacts were investigated focusing grain yield, grain-N, and quality parameters (i.e., crude protein, gluten, amylose and amylopectin). Experiment was a randomized complete block, in three replications, conducted at Agronomy Res. Farm of the University of Agric. Peshawar in 2016-17 and repeated in 2017-18. Results showed the highest NUE in $100 \mathrm{~kg} \mathrm{~N} \mathrm{ha}^{-1}$, followed by a decreasing rate $(\mathrm{p}<0.05)$ for every next $\mathrm{N}$-increment. While averaged on N-rates, the highest NUE observed in $\mathrm{NAT}_{3}$ which did not differ fromNAT 4 but decreased $(\mathrm{p}<0.05)$ for treatment $\mathrm{NAT}_{2}$ with lowest for theNAT ${ }_{1}$. Pakhtunkhuwa-2015 showed higher NUE among the varieties. Grain-N, grain yield, gluten and amylose did not differ with NAR 140 and $160 \mathrm{~kg} \mathrm{ha}^{-1}$ as well as for the NAT 3 and NAT 4 but decreased for NAT 2 and the lowest was noted for $\mathrm{NAT}_{1}$. The N-content of wheat grain was highest in Pakhtunkhuwa-2015, followed by Pirsabak-2015 and the lowest in DN-84. Nonetheless, grain amylopectin showed a reduction with increasing NAR and/or split N-applications from one to two and/or three doses. Cultivars did not show any changes in the amylopectin. It is concluded that in recent climate changes where flood irrigation system is practiced, three $\mathrm{N}$-splits $\left(\mathrm{NAT}_{3}\right.$ or $\mathrm{NAT}_{4}$ ) resulted higher quality grains with140 $\mathrm{kg} \mathrm{N} \mathrm{ha}^{-1}$ to wheat crop.
\end{abstract}

Keywords: Nitrogen rate, nitrogen timing, N-use efficiency, yield traits and grain yield, wheat varieties.

\section{INTRODUCTION}

Wheat (Triticum aestivum L.), being an important cereal crop grown throughout the globe, is a major source of staple food and feed for living being. It is one of the most important crops in central Asia and Pakistan, used as a staple food to meet nutritional requirements with higher calories and protein of an average human diet (Adhikari et al., 2017). On average, it provides $22 \%$ protein and $20 \%$ calories (Pfeifer et al., 2014) and is extensively used in food due to gluten properties (Elli et al., 2015). Gluten is gliadin and glutenin, and its viscosity linked with the gliadin (Barak et al., 2013). Agronomic and genetics techniques are adopted to unravel the wheat flour and backing quality (Sher, 2019). Particularly, the $\mathrm{N}$ fertilization regulates rate and timing to harvest better quality grains for backing.
Nitrogen (N) is an important component of chlorophyll, various hormones, nucleotides, vitamins and enzymes supported vegetative growth of plants (Delloye et al., 2018) Nitrogen is a major constituent of amino acids, building blocks of proteins, essential for grains formation (Duan et al., 2020) and to harvest the optimum yield (Preece et al., 2017). Balanced $\mathrm{N}$ application rate and timings to the crop is a key for successful production (Aczel, 2019). Nitrogen is one of the most important inorganic fertilizer, consumed the maximum than any other nutrients and a major limiting factor of plant growth in term of yield and quality of the finish product (Agegnehu et al., 2016). Nitrogen plays a fundamental role in improving wheat grain quality (Medford et al., 2017). Initially, single $\mathrm{N}$ application was recommended for the cop growth and development, followed by two splits

Khan, G.R. and M. Akmal. 2021. Nitrogen application rate and timing management for improved grain quality parameters of wheat crop. Pak. J. Agri. Sci. 58: 1141-1153.

[Received 22 Jan 2020; Accepted 6 Jul 2021; Published (online) 21 Sep 2021] 
with good responses (Adeyemi et al., 2020). The recent changes in seasonal climate have also changed the pattern of rainfall and durations, which is expected to be continued till 2040 in Pakistan (Asim et al., 2013; Hanif and Ali, 2014). During these changes, wheat crop will adversely be affected in rainfed areas at sowing time and higher infestation of disease and insect attach in irrigated land closer to the anthesis stage of growth and development. Nitrogen under dryland and/or excessive rainfalls will be lost by leaching and volatilization in soil (Jones et al., 2013; Ni et al., 2014). To avoid such N-loss, it is important to focus on application timing with proper rates subjected to the plant growth and development for optimum utilization. This would not only decrease the input costs of production but also increase the NUE with better quality grain (Cormier et al., 2016; Herrera et al., 2016). Moreover, the $\mathrm{N}$ application rate can optimize growth and grain $\mathrm{N}$ content, protein and baking quality (Ooro et al., 2011; Xue et al., 2019) as quality relates to gliadins and glutenin strengthening viscosity and extensibility (Cappelli et al., 2020). Split $\mathrm{N}$-application has strengthened flour loaf volume (Xueet al., 2019). Protein content of wheat grains depends upon the $\mathrm{N}$-application rate, timing, soil fertility, cultivar and climatic condition (Geleta et al., 2002). For better grain yield, crude protein and nitrogen use efficiency (NUE), split $\mathrm{N}$-application during growth is more effective (Mohemmed et al., 2013). Nitrogen fertilization plays important role for yield and quality and can easily be adjusted with application of optimum $\mathrm{N}$ rate corresponds with the crop growth (Zoerb et al., 2010). Nitrogen application at different stages of the plant (e.g., sowing, tillering and booting) has increased N-uptake, NUE, starch and protein content of grains (Da-Moraes et al., 2013). To produce higher grain yield and with better quality, $\mathrm{N}$ should be applied with corresponds to growth stages of the crop (Leghari et al., 2016). On the other hand, increasing NUE, proper N-rate and application timings, as fertilizer, is essential for good crop husbandry and grain quality (Hirel et al., 2011). For good baking quality, grains must have enough protein content, which can be sustained to be made available in the soil at the time of grain development (Blumenthal et al., 2008). The recent climate shift in Pakistan has shown an increase in rainfall intensity and duration when wheat enters in reproductive stages of the growth (Hanif and Ali, 2014). Focusing $\mathrm{N}$-application timing and rates for wheat as staple food crop is of high significant to address grain yield and quality (Beleta et al., 2018).

This study was, therefore, conducted to elucidate multiple split $\mathrm{N}$ application timing and $\mathrm{N}$-application rates addressing the spring wheat yield, grain $\mathrm{N}$-content, gluten, amylose and amylopectin, which adds in loaf volume, baking quality and kneading rheology of the crop. Nitrogen is highly mobile in soil and is applied in greater quality than any other nutrient in two splits and recent climate change has shown higher rainfalls in wheat reproductive stage.

\section{MATERIALS AND METHODS}

Experimental station: Two years field experiments were conducted at Agronomy Research Farm, the University of Agriculture Peshawar-Pakistan located at $\left(34.01^{\circ} \mathrm{N}, 71.35^{\circ} \mathrm{E}\right.$, altitude $350 \mathrm{~m}$ and $1600 \mathrm{~km}$ North of the Indian ocean). Climate of the Peshawar is semi-arid, relatively hot summer with mild cool and relatively shorter winter. The mean maximum and minimum temperatures of summer are 25-40 ${ }^{\circ} \mathrm{C}$ and winter $4-18^{\circ} \mathrm{C}$. Soil is, relatively silt loam, alkaline and low in organic matter. Weather data such as maximum, minimum temperatures $\left({ }^{\circ} \mathrm{C}\right)$ and rainfall $(\mathrm{mm})$ of the crop growth period are shown in Fig. 1.

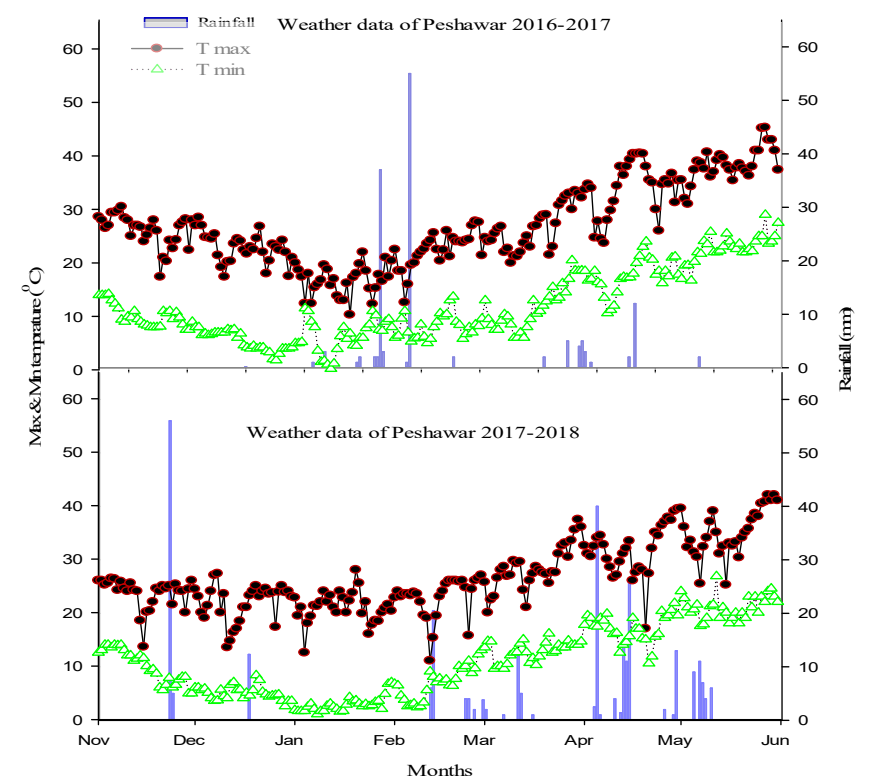

Figure 1. Daily rainfall (vertical bar), mean maximum and minimum temperature (line) of experimental location for the crop growth seasons (2016-17 and 2017-18).

Experiment details: To plant the crop, seedbed was prepared as recommended for wheat in the area. Field after maize harvesting was plowed with cultivator and subsequently planked. The experiment was laid out in randomized complete block design with split plots arrangements using three replications. Pre-basic seeds of wheat (cv. Pakhtunkhwa-2015 which is recommended for both rain-fed and irrigated area, DN-84 approved for rain-fed and Pirsabak-2015 recommended as irrigated) were planted on November 21, 2016, and November 29, 2017, using same seed rate $120 \mathrm{~kg}$ $\mathrm{ha}^{-1}$ for all varieties. Planting was made manually using a hand-driven hoe. Phosphorus $\left(90 \mathrm{~kg} \mathrm{ha}^{-1}\right)$ and potassium $(60$ $\mathrm{kg} \mathrm{ha}^{-1}$ ) were applied as recommend at the time of the seedbed preparation using single super phosphate $(18 \%)$ and Muriate of potash $(60 \%)$. Nitrogen was applied in different rates (i.e., $0,100,120,140$ and $160 \mathrm{~kg} \mathrm{ha}^{-1}$ ) on different stages 
i.e. at sowing time 0 days after sowing (DAS), tillering (70 DAS) and at the crop booting stages (100 DAS) using urea source $(\mathrm{N}-46 \%)$. The different $\mathrm{N}$-timings were $\mathrm{NAT}_{1}$ (Single application at seedbed preparation), $\mathrm{NAT}_{2}$ (Two splits $50 \%$ at sowing and $50 \%$ at tillering), $\mathrm{NAT}_{3}$ (three splits $25 \%$ at sowing, $50 \%$ at tillering and $25 \%$ at booting) and $\mathrm{NAT}_{4}$ (three splits $25 \%$ at sowing, $25 \%$ at tillering and $50 \%$ at booting) of the suggested rates. Field was irrigated uniformly at tillering, booting and grain filling stages as per crop water need. All other practices were kept uniform for the experimental units. Herbicide (Affinity 50WP, 2.0) was used for weeds control at tillering stage once as post emergence spray.

Grain yield: Grain yield $\left(\mathrm{g} \mathrm{m}^{-2}\right)$ was recorded by harvesting four central rows in an experimental unit, bundled and dried for 10 days in field. Dried bundles were threshed on a mini lab wheat thresher. Grains were collected, weighed and adjusted for grains moisture content ( $16 \%$ grain moisture) to estimate the grain yield.

Nitrogen content: Grain N-content was determined in composite samples (\%) taken from all experimental units after threshing the crop. Sample was dried, ground (Cyclone Mill Twister), conserved and analyzed for grain $\mathrm{N}$-content. Nitrogen was determined by Kjeldahl method (Kozin et al., 2019). Briefly, grain and straw samples were weighed $(0.2 \mathrm{~g})$, added with $1.3 \mathrm{~g}$ of digestion mixture $\left(\mathrm{CuSO}_{4} 10 \mathrm{~g}+\right.$ $\mathrm{K}_{2} \mathrm{SO}_{4} 100 \mathrm{~g}$ and selenium metal powder $1 \mathrm{~g}$ ) included $3 \mathrm{ml}$ of concentrated $\mathrm{H}_{2} \mathrm{SO}_{4}$ in a digestion tube and assembled. Contents of digestion tube was heated continuously till solution became clear greenish, filtered, volume made $100 \mathrm{ml}$ and transferred to a Kjeldhal apparatus. A $20 \mathrm{ml}$ sample was added with $4 \mathrm{ml} \mathrm{NaOH}$ solution and heated for distillation, distillate was collected in a flask containing $5 \mathrm{ml}$ of already made boric acid mixed indicator and heated till yellowish color appeared. Distillate was titrated with $0.005 \mathrm{~N} \mathrm{HCl}$. Readings for sample as well as blank was recorded. Total Ncontent was derived as mean value of grain of the treatments. Respective N-content multiplied with a factor (6.25) for crude protein determination.

$\boldsymbol{N}$ use efficiency: Nitrogen use efficiency (NUE) was derived as per procedure explained by Fageria and Nascente (2014). Briefly explained as the ratio of the grain weight harvested from a plot treated with a N-rate less yield of the control plot divided by the given N-rate to that plot. The reading of NUE was expressed in percentages.

Seed gluten: Hand wash method was used for seed gluten (\%) determination (Sayaslan et al., 2006). Grains were ground in a mini-lab grinding mill (Cyclone Mill Twister, $50 / 60 \mathrm{~Hz}$ ). A $25 \mathrm{~g}$ sample collected, mixed with $15 \mathrm{ml}$ of water to form wet dough. Dough was allowed to stand for an hour. All starch and soluble matter were removed by pressing dough in water flowing in a plastic dish. Dough-ball was placed in a tarred, flat-bottom dish and weighted as wet gluten. Dough-ball was dried at $100^{\circ} \mathrm{C}$ in an oven for dry gluten content. Gluten (\%) was determined by taking ratio of wet gluten over the sample weight and expressed value in percentages.

Amylose content: Amylase (\%) was determined by iodine calorimetric method (Nakamura et al., 2020). Grains were grounded and passed through a $100 \mathrm{~mm}$ mesh. Sample of 100 $\mathrm{mg}$ was taken in triplicate in $100 \mathrm{ml}$ flask, added with $1.0 \mathrm{ml}$ (95\%) ethanol and $9 \mathrm{ml} \mathrm{NaOH}$ (IM) solution. Contents of flasks were boiled in a water-bath for 10 minutes to gelatinize the starch. Boiled samples were allowed to rest for a while, volume was made to $100 \mathrm{ml}$ by adding distilled water and store at the room temperature $\left(25^{\circ} \mathrm{C}\right)$ for $23 \mathrm{~h}$. A blank was also prepared in addition to sample for correction. Solution in flask was mixed, a $5.0 \mathrm{ml}$ sample was pipetted into another $100 \mathrm{ml}$ flask, $1 \mathrm{ml}$ of glacial acetic acid (I M) and $2 \mathrm{ml}$ iodine ( $\mathrm{I}_{2}$ is insoluble in water, $2 \mathrm{~g}$ potassium iodide in $900 \mathrm{ml}$ of distilled water was added in $1 \mathrm{~g}$ iodine crystals), adjusted volume $900 \mathrm{ml}$ with distilled water. Sample was mixed and rest for 20 minutes, which developed a dark blue color. Spectrophotometer was calibrated to run standard at $620 \mathrm{~nm}$ spectrum along with all samples. Value of absorbance was converted to amylose using standard calibration curve developed from the pure potato amylose (Fig. 2).

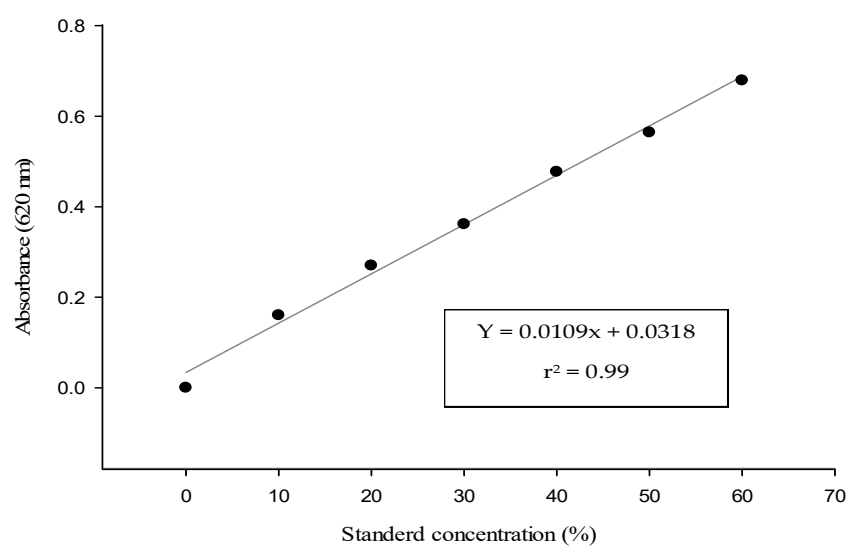

Figure 2. Amylose standard curve developed for amylose in wheat grains. Solid dot shows actual value against the regression.

Amylose curve: Pure amylose $12.5 \mathrm{mg}(0.0125 \mathrm{~g})$ and amylopectin $12.5 \mathrm{mg}$ were taken in separate tube, added with $5 \mathrm{ml}$ of $45 \%$ perchloric acid and dissolved. Bring final volume to $50 \mathrm{ml}$ with distilled water. A $6.25 \mathrm{ml}$ amylose stock from $50 \mathrm{ml}$, added with $18.75 \mathrm{ml}$ ultra-pure water to make 6.25 $\mathrm{mg} / \mathrm{ml}$ amylose solution, repeated the same procedure for amylopectin solution. Using this stock solution, standard solution of amylose and amylopectin was prepared in percent $(0,10,20,30,40,50$ and $60 \%)$ to a final volume of $5 \mathrm{ml}$ to create standard curve. For example, to prepare $0 \%$ amylose / $100 \%$ amylopectin standard, pipette $5 \mathrm{ml}$ amylopectin solution. A 10\% amylose / 90\% amylopectin standard combined $0.5 \mathrm{ml}$ amylose and $4.5 \mathrm{ml}$ amylopectin solution. A $20 \%$ amylose $/ 80 \%$ amylopectin standard combine $1.0 \mathrm{ml}$ 
amylose and $4.0 \mathrm{ml}$ of amylopectin solutions the same ratio $(0.5)$ were used for $10 \%$ intervals. Transfer $40 \mu \mathrm{l}$ of a standard mixture to a micro-titer plate. Add $50 \mu$ l of iodine solution ( 2 $\mathrm{g} \mathrm{KI}+1 \mathrm{~g} \mathrm{I}_{2}$ in $900 \mathrm{ml}$ of ultra-pure water) and mix each sample including blank (perchloric acid) by pipetting. Read absorbance at $620 \mathrm{~nm}$ immediately and calculate amylose ratio for a concentration. A standard calibration curve was developed using different concentrations and their absorbance (Fig. 2).

Statistical analysis: Data were statistically analyzed using analysis of variance techniques appropriate for randomized complete block design with split plot arrangements (Izenman, 2008; Box, Jones, 1992) for a single year and two years averages. R-3.5.3 software was used for analyzing the data. Means were separated using the least significance difference (LSD) test at a 5\% level of significance.

\section{RESULTS}

Grain N-content and grain yield: Grain N-content (GNC) as influenced by nitrogen application rate (NAR, nitrogen application timing (NAT) and varieties revealed a significant change (Table 1). Averaged across NAT and varieties, GNC affected $(\mathrm{p}<0.05)$ with highest for $140 \mathrm{~kg} \mathrm{ha}^{-1}$ which did not differ $(\mathrm{p}<0.05)$ from $160 \mathrm{~kg} \mathrm{ha}^{-1}$. The NAR $100 \mathrm{~kg} \mathrm{ha}^{-1}$ also did not differ $(\mathrm{p}<0.05)$ from $120 \mathrm{~kg} \mathrm{ha}^{-1}$ with lowest reading for control $\left(0 \mathrm{~kg} \mathrm{ha}^{-1}\right)$. Regarding NAT, three splits (i.e., $\mathrm{NAT}_{3}$ ) resulted in high GNC, which was statistically similar with $\left(\mathrm{NAT}_{4}\right)$. Two splits $\left(\mathrm{NAT}_{2}\right)$ were lower for GNC and lowest GNC under $\mathrm{NAT}_{1}$. While averaged across NAR and NAT, varieties showed differences in GNC with highest in Pakhtunkhwa-2015, followed by Pirsabak-2015 and lowest in DN-84. Among interactions, NAR $x \mathrm{~V}$ was significant (Fig. 3).

GNC showed a visible increment for all varieties when NAR increased from 0 to $100 \mathrm{~kg} \mathrm{ha}^{-1}$, thereafter GNC leveled off in all three varieties by increasing NAR from 100 to $160 \mathrm{~kg} \mathrm{ha}^{-1}$. Nevertheless, Pakhtunkhuwa-2015 was better than Pirsabak2015, which was followed by DN-84 at any given N-rate from 100 to $160 \mathrm{~kg} \mathrm{ha}^{-1}$.

Table 1. Grain and tissue nitrogen $\left(\mathrm{kg} \mathrm{ha}^{-1}\right)$ of wheat as influenced by $\mathrm{N}$-application rates (NAR) and $\mathrm{N}$-application timings (NAT).

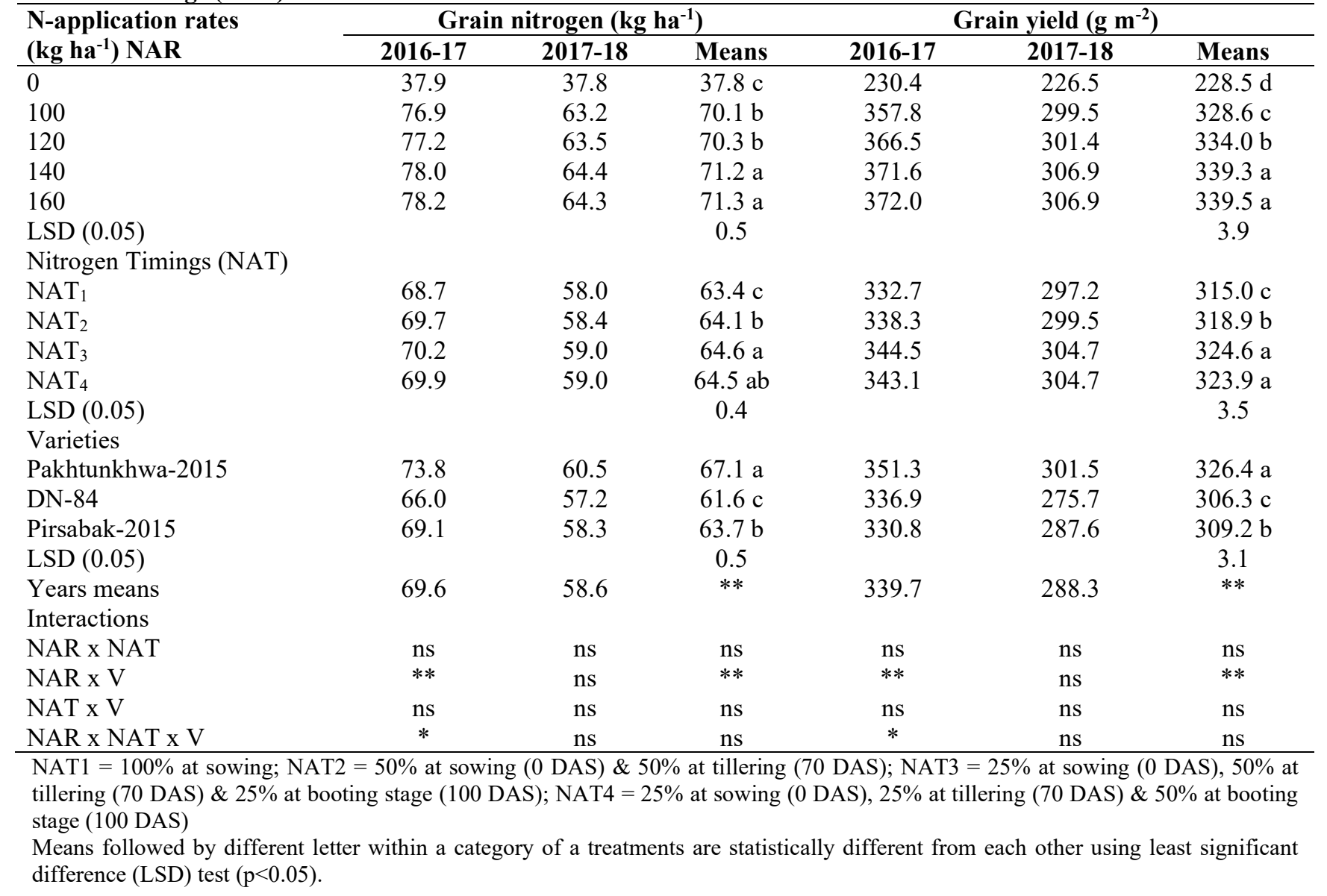




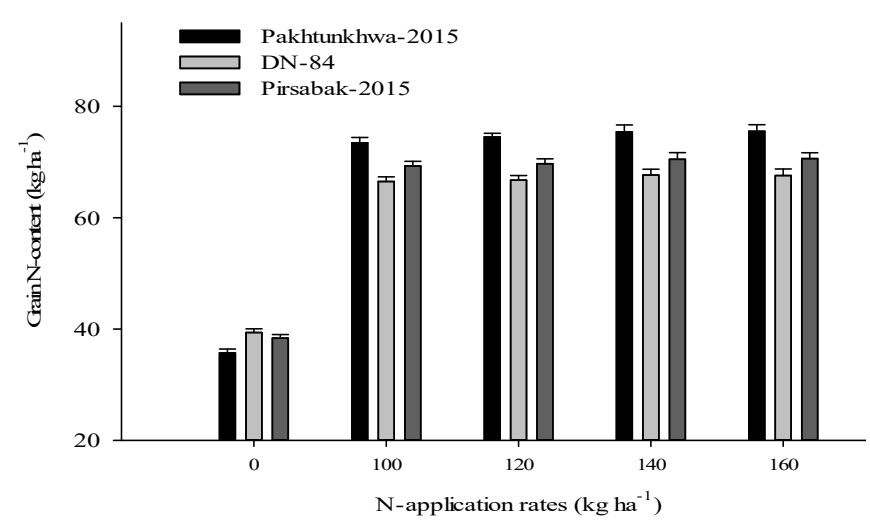

Figure 3. Grain nitrogen $\left(\mathrm{kg} \mathrm{ha} \mathrm{ha}^{-1}\right)$ of treatment interactions [ $\mathrm{N}$ application rates (NAR) $\mathrm{x}$ wheat variety].

Grain yield $\left(\mathrm{g} \mathrm{m}^{-2}\right)$ as influenced by NAR, NAT and cultivars showed significant responses to the given treatments (Table 1). While averaged across NAT and cultivars, the maximum grain yield was reported under NAR $140 \mathrm{~kg} \mathrm{ha}^{-1}$ which did not differ from treatment NAR $160 \mathrm{~kg} \mathrm{ha}^{-1}$, followed by NAR 120 and $100 \mathrm{~kg} \mathrm{ha}^{-1}$. The minimum grain yield was observed in control treatment $\left(0 \mathrm{~kg} \mathrm{ha}^{-1}\right)$. Irrespective of the NAR and cultivars, grain yield showed changes $(p<0.05)$ with NAT with maximum yield in three splits $\left(\mathrm{NAT}_{3}\right.$ or $\mathrm{NAT}_{4}$ ) with either splits-application ratios, followed by two splits $\left(\mathrm{NAT}_{2}\right)$ and the minimum for single application (NAT ${ }_{1}$ ). Among the cultivars, Pakhtunkhwa-2015 showed higher grain yield, followed by Pirsabak-2015 and the lower for DN-84. Among treatment interaction (NAR $\times \mathrm{V}$ ) was significant for grain yield almost same response for grain yield, variety Pakhtunkhuwa-15 and Pirsabak-15 showed prominent increase as compared to $\mathrm{DN}-84$ at any NAR (Fig. 4).

Nitrogen use efficiency (\%): Nitrogen use efficiency (NUE) as influenced by NAR, NAT and wheat was significant (Table 2). Averaged across NAT and varieties, increasing NAR from 100 to $160 \mathrm{~kg} \mathrm{ha}^{-1}$ has showed a significant decrease with each increment. Obviously, the maximum NUE was recorded in the $100 \mathrm{~kg} \mathrm{~N} \mathrm{ha}^{-1}$, which decreased $(\mathrm{p}<0.05)$ for 120 and $140 \mathrm{~kg} \mathrm{~N} \mathrm{ha}^{-1}$. The lowest NUE was observed at $160 \mathrm{~kg} \mathrm{ha}^{-1}$. Means across NAR and varieties, NAT did differ in NUE with highest for three splits (i.e. $\mathrm{NAT}_{3}$ ), followed by

Table 2. Nitrogen use efficiency (\%) and crude protein (\%) of wheat as influenced by $\mathrm{N}$-application rates (NAR) and $\mathrm{N}$-application timings (NAT).

\begin{tabular}{|c|c|c|c|c|c|c|}
\hline \multirow{2}{*}{$\begin{array}{l}\text { N-application rates } \\
\left(\mathrm{kg} \mathrm{ha}^{-1}\right) \text { NAR }\end{array}$} & \multicolumn{3}{|c|}{ Nitrogen use efficiency $(\%)$} & \multicolumn{3}{|c|}{ Crude protein (\%) } \\
\hline & 2016-17 & 2017-18 & Means & 2016-17 & 2017-18 & Means \\
\hline 0 & - & - & - & 9.8 & 9.5 & $9.6 \mathrm{c}$ \\
\hline 100 & 35.8 & 36.6 & $36.2 \mathrm{a}$ & 12.3 & 11.9 & $12.1 \mathrm{~b}$ \\
\hline 120 & 30.5 & 30.3 & $30.4 \mathrm{~b}$ & 12.6 & 11.8 & $12.2 \mathrm{~b}$ \\
\hline 140 & 26.5 & 27.2 & $26.8 \mathrm{c}$ & 13.0 & 12.1 & $12.6 \mathrm{a}$ \\
\hline 160 & 24.6 & 24.6 & $23.9 \mathrm{~d}$ & 12.7 & 12.9 & $12.8 \mathrm{a}$ \\
\hline $\operatorname{LSD}(0.05)$ & & & 0.5 & & & 0.3 \\
\hline \multicolumn{7}{|c|}{ Nitrogen Timings (NAT) } \\
\hline $\mathrm{NAT}_{1}$ & 28.3 & 27.6 & $28.0 \mathrm{c}$ & 11.7 & 11.2 & $11.4 \mathrm{~b}$ \\
\hline $\mathrm{NAT}_{2}$ & 28.9 & 29.7 & $29.3 \mathrm{~b}$ & 11.7 & 11.2 & $11.4 \mathrm{~b}$ \\
\hline $\mathrm{NAT}_{3}$ & 29.5 & 30.7 & $30.1 \mathrm{a}$ & 12.3 & 11.5 & $11.9 \mathrm{a}$ \\
\hline $\mathrm{NAT}_{4}$ & 29.4 & 30.6 & $30.0 \mathrm{a}$ & 12.7 & 11.1 & $11.9 \mathrm{a}$ \\
\hline $\operatorname{LSD}(0.05)$ & & & 0.50 & & & 0.2 \\
\hline \multicolumn{7}{|l|}{ Varieties } \\
\hline Pakhtunkhwa-2015 & 30.1 & 29.5 & $29.8 \mathrm{a}$ & 11.7 & 11.2 & $11.5 \mathrm{c}$ \\
\hline DN-84 & 28.7 & 29.3 & $29.0 \mathrm{~b}$ & 12.1 & 11.6 & $11.8 \mathrm{~b}$ \\
\hline Pirsabak-2015 & 28.2 & 30.2 & $29.2 \mathrm{~b}$ & 12.5 & 12.1 & $12.3 \mathrm{a}$ \\
\hline $\operatorname{LSD}(0.05)$ & & & 0.3 & & & 0.2 \\
\hline Years means & 29.0 & 29.7 & Ns & 12.1 & 11.6 & Ns \\
\hline \multicolumn{7}{|l|}{ Interactions } \\
\hline NAR $x$ NAT & Ns & ns & ** & Ns & ns & ** \\
\hline NAR x V & Ns & ns & Ns & ** & ns & Ns \\
\hline NAT x V & Ns & $\mathrm{ns}$ & Ns & Ns & $\mathrm{ns}$ & $*$ \\
\hline NAR x NAT $x$ V & Ns & $\mathrm{ns}$ & Ns & * & ns & Ns \\
\hline
\end{tabular}


$\mathrm{NAT}_{4}$ and two splits (i.e. $\mathrm{NAT}_{2}$ ) with lowest for single application. On averaged across NAR and NAT, varieties found significant for NUE with higher for Pakhtunkhwa2015, followed by DN-84, which did not differ from Pirsabak2015. Among interaction, only NAR x NAT was significant for NUE (Fig. 5). Better NUE observed under three splits (i.e. $\mathrm{NAT}_{3}$ and $\left.\mathrm{NAT}_{4}\right)$, followed by two splits $\left(\mathrm{NAT}_{2}\right)$ and lowest under $\mathrm{NAT}_{1}$ with decreasing trend for increased NAR.



Figure 4. Grain yield $\left(\mathrm{g} \mathrm{m}^{-2}\right)$ of treatment interaction [N application rates (NAR) $\mathrm{x}$ wheat variety].

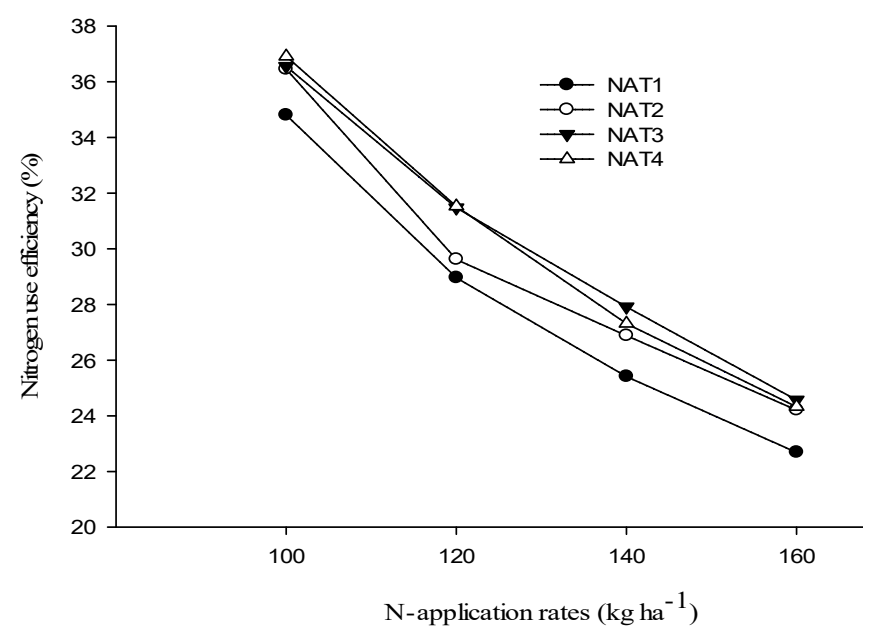

Figure 5. Nitrogen use efficiency (\%) of treatment interactions [N-application rates (NAR) and $\mathrm{N}$ application timings (NAT)].

Crude protein (\%): Grain protein content (CP) as affected by NAR, NAT and varieties is shown in Table 2. While averaged across NAT and varieties, the NAR $140 \mathrm{~kg} \mathrm{ha}^{-1}$ showed higher $\mathrm{CP}$ which did not vary $(\mathrm{p}<0.05)$ from $160 \mathrm{~kg} \mathrm{~N} \mathrm{ha}^{-1}$. CP did differ from $120 \mathrm{~kg} \mathrm{ha}^{-1}$, followed by $100 \mathrm{~kg} \mathrm{ha}^{-1}$ with the lowest in control treatment. When averaged across NAR and varieties, the $\mathrm{CP}$ was highest in three splits $\left(\mathrm{NAT}_{3}\right)$ with similar for $\mathrm{NAT}_{4}$. CP of grains was reported lowest in $\mathrm{NAT}_{1}$ that did not differ from $\mathrm{NAT}_{2}$. Pirsabak-2015 showed higher
$\mathrm{CP}$ in grain, followed by Pakhtunkhwa-15 and lowest in DN84. Interaction NAR x NAT was significant $(p<0.05)$ with increasing trends for all NAT by increase NAR (Fig. 6). Difference in CP of varieties under NAT at any increment of NAR showed visible differences at NAR 120 and $160 \mathrm{~kg} \mathrm{ha}^{-1}$. Both $\mathrm{NAT}_{3}$ and $\mathrm{NAT}_{4}$ performed better $\mathrm{CP}$ in grains at 140

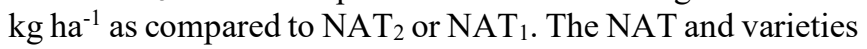
showed a significant effect in grain CP (Fig. 7). Pirsabak2015 was good, followed by DN-84 and Pakhtunkhuwa-2015 at any given NAT with more clear differences for $\mathrm{NAT}_{3}$ and $\mathrm{NAT}_{4}$.

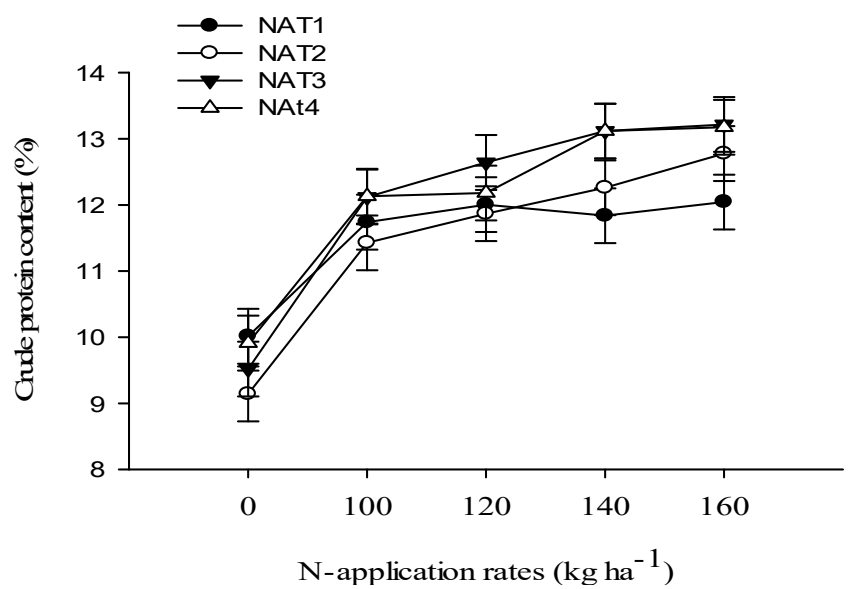

Figure 6. Crude protein (\%) of treatment interactions [Napplication rates (NAR) and $\mathrm{N}$-application timings].

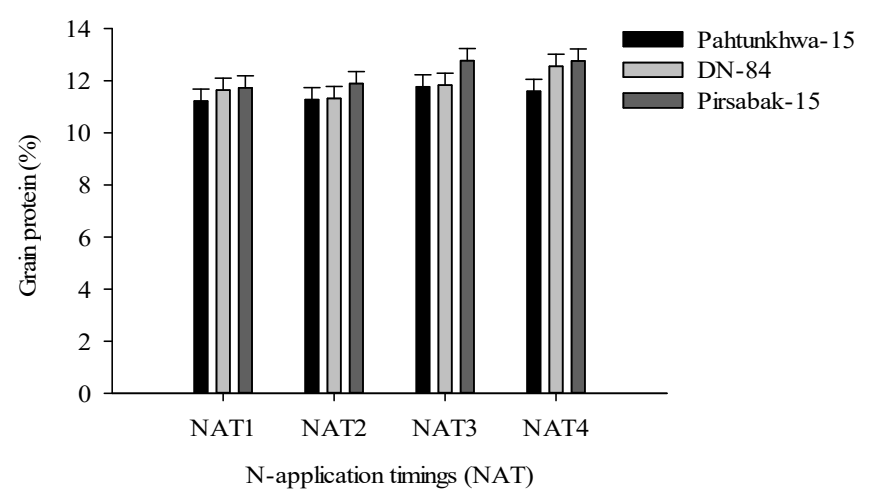

Figure 7. Crude protein content (\%) of treatment interactions [N-application timings (NAT) and wheat varieties].

Wet gluten ((\%): Wet gluten content (WGC) was significantly affected by NAR, NAT and verities (Table 3 ). While averaged across NAT and varieties, the highest WGC was observed at NAR $140 \mathrm{~kg} \mathrm{ha}^{-1}$, which was statistically similar to $160 \mathrm{~kg} \mathrm{ha}^{-1}$. The WGC observed at $120 \mathrm{~kg} \mathrm{ha}^{-1}$ differed $(p<0.05)$ from $100 \mathrm{~kg} \mathrm{ha}^{-1}$ with lowest in control. While mean across NAR and varieties, the highest WGC recorded at $\mathrm{NAT}_{4}$, followed by $\mathrm{NAT}_{3}$ and $\mathrm{NAT}_{2}$ with the 
lowest in $\mathrm{NAT}_{1}$. Pirsabak-2015 showed higher WGC which was similar with DN-84 and lower in Pakhtunkhwa-2015. Treatment interaction NAR $\mathrm{x}$ NAT was found significant for WGC (Fig. 8).

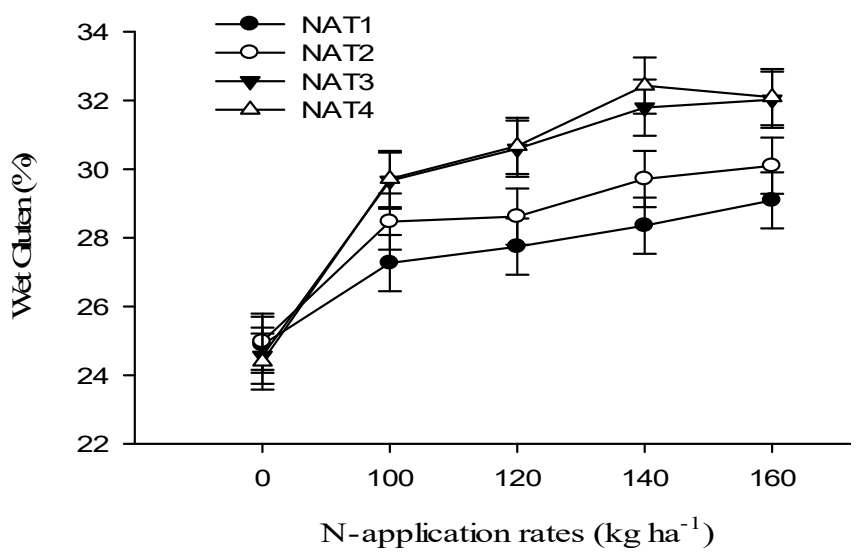

Figure 8. Wet gluten content (\%) of treatments interaction $[\mathbf{N}$-application rates (NAR) and $\mathbf{N}$-application timing (NAT)].
Figure showed an increase in NAR from $0 \mathrm{~kg} \mathrm{~N} h a^{-1}$ onwards showed an increasing trend for WGC with marked differences for NAT at NAR 100 approaching to $160 \mathrm{~kg} \mathrm{ha}^{-1}$. Visible difference in WGC was observed under three splits when compared with two or single splits at $140 \mathrm{~kg} \mathrm{ha}^{-1}$. Thereafter, WGC of wheat at NAR 120 and $160 \mathrm{~kg} \mathrm{ha}^{-1}$ did not show a clear response for any NAT.

Dry gluten (\%): Dry gluten content (DGC) in grain as affected by NAR, NAT and varieties reported significant (Table 3). Averaged across NAT and varieties, the DGC was significantly affected by NAR with maximum for $140 \mathrm{~kg} \mathrm{ha}^{-1}$ with non-significant change from $160 \mathrm{~kg} \mathrm{ha}^{-1}$, followed by 120 and $100 \mathrm{~kg} \mathrm{ha}^{-1}$. The minimum DGC was noted in control. When averaged across NAR and $\mathrm{V}$, highest DGC reported in three splits $\left(\mathrm{NAT}_{3}\right.$ and $\mathrm{NAT}_{4}$ ), followed by two splits $\left(\mathrm{NAT}_{2}\right)$ and minimum by $\mathrm{NAT}_{1}$. The DGC in varieties did not differ $(p<0.05)$. Interaction NAR $x$ NAT showed change in DGC which were increased with increasing NAR in all NAT but with different readings at a given NAR for splits over sole applications. DGC at NAR $100 \mathrm{~kg} \mathrm{ha}^{-1}$ were higher for all NAT when compared with control. Thereafter, differences expanded for NAT at NAR 120 with highest at $140 \mathrm{~kg} \mathrm{ha}^{-1}$

Table 3. Wet and dry gluten content (\%) of wheat crop as influenced by $\mathrm{N}$-application rates (NAR) and $\mathrm{N}$ application timings (NAT).

\begin{tabular}{|c|c|c|c|c|c|c|}
\hline \multirow{2}{*}{$\begin{array}{l}\text { N-application rates } \\
\left(\mathrm{kg} \mathrm{ha}^{-1}\right) \text { NAR }\end{array}$} & \multicolumn{3}{|c|}{ Wet gluten (\%) } & \multicolumn{3}{|c|}{ Dry gluten (\%) } \\
\hline & 2016-17 & 2017-18 & Means & 2016-17 & 2017-18 & Means \\
\hline 0 & 26.4 & 25.5 & $26.0 \mathrm{~d}$ & 8.5 & 8.7 & $8.6 \mathrm{~d}$ \\
\hline 100 & 30.1 & 27.5 & $28.8 \mathrm{c}$ & 10.9 & 11.0 & $10.9 \mathrm{c}$ \\
\hline 120 & 30.3 & 28.6 & $29.4 \mathrm{~b}$ & 11.1 & 11.2 & $11.1 \mathrm{~b}$ \\
\hline 140 & 31.4 & 29.7 & $30.6 \mathrm{a}$ & 11.4 & 11.3 & $11.3 \mathrm{a}$ \\
\hline 160 & 31.8 & 29.8 & $30.8 \mathrm{a}$ & 11.5 & 11.4 & $11.4 \mathrm{a}$ \\
\hline $\operatorname{LSD}(0.05)$ & & & 0.4 & & & 0.2 \\
\hline \multicolumn{7}{|c|}{ Nitrogen Timings (NAT) } \\
\hline $\mathrm{NAT}_{1}$ & 28.0 & 26.9 & $27.4 \mathrm{~d}$ & 10.4 & 10.5 & $10.4 \mathrm{~b}$ \\
\hline $\mathrm{NAT}_{2}$ & 29.8 & 26.7 & $28.2 \mathrm{c}$ & 10.5 & 10.6 & $10.6 \mathrm{~b}$ \\
\hline $\mathrm{NAT}_{3}$ & 31.0 & 28.7 & $29.9 \mathrm{~b}$ & 10.8 & 10.9 & $10.9 \mathrm{a}$ \\
\hline $\mathrm{NAT}_{4}$ & 31.2 & 29.0 & $30.1 \mathrm{a}$ & 10.9 & 10.8 & $10.9 \mathrm{a}$ \\
\hline $\operatorname{LSD}(0.05)$ & & & 0.4 & & & 0.2 \\
\hline \multicolumn{7}{|l|}{ Varieties } \\
\hline Pakhtunkhwa-2015 & 29.7 & 27.8 & $28.8 \mathrm{~b}$ & 10.7 & 10.7 & $10.7 \mathrm{a}$ \\
\hline DN-84 & 30.1 & 28.1 & $29.1 \mathrm{a}$ & 10.7 & 10.7 & $10.7 \mathrm{a}$ \\
\hline Pirsabak-2015 & 30.2 & 28.7 & $29.5 \mathrm{a}$ & 10.7 & 10.7 & $10.7 \mathrm{a}$ \\
\hline $\operatorname{LSD}(0.05)$ & & & 0.3 & & & Ns \\
\hline Years means & 30.0 & 28.2 & $* *$ & 10.7 & 10.7 & Ns \\
\hline \multicolumn{7}{|l|}{ Interactions } \\
\hline NAR $x$ NAT & Ns & ns & $* *$ & Ns & ns & $* *$ \\
\hline NAR $x$ V & $* *$ & $\mathrm{~ns}$ & Ns & $* *$ & ns & Ns \\
\hline NAT x V & Ns & ns & Ns & Ns & ns & Ns \\
\hline NAR $x$ NAT $x$ V & * & ns & Ns & $*$ & ns & Ns \\
\hline
\end{tabular}


Table 4. Amylose and amylopectin content (\%) of wheat crop as influenced by $\mathrm{N}$-application rates (NAR) and $\mathrm{N}$ application timings (NAT).

\begin{tabular}{|c|c|c|c|c|c|c|}
\hline \multirow{2}{*}{$\begin{array}{l}\text { N-application rates } \\
\left(\mathrm{kg} \mathrm{ha}^{-1}\right) \text { NAR }\end{array}$} & \multicolumn{3}{|c|}{ Amylose content (\%) } & \multicolumn{3}{|c|}{ Amylopectin (\%) } \\
\hline & 2016-17 & 2017-18 & Means & 2016-17 & 2017-18 & Means \\
\hline 0 & 18.2 & 17.3 & $17.7 \mathrm{~d}$ & 83.3 & 84.4 & $83.9 \mathrm{a}$ \\
\hline 100 & 21.8 & 21.6 & $21.7 \mathrm{c}$ & 79.4 & 78.9 & $79.2 \mathrm{~b}$ \\
\hline 120 & 23.5 & 22.1 & $22.8 \mathrm{~b}$ & 77.9 & 79.1 & $78.5 \mathrm{~b}$ \\
\hline 140 & 23.8 & 23.8 & $23.8 \mathrm{a}$ & 77.2 & 77.2 & $77.2 \mathrm{c}$ \\
\hline 160 & 23.9 & 24.0 & $23.9 \mathrm{a}$ & 77.2 & 77.0 & $77.1 \mathrm{c}$ \\
\hline $\operatorname{LSD}(0.05)$ & & & 0.7 & & & 0.9 \\
\hline \multicolumn{7}{|c|}{ Nitrogen Timings (NAT) } \\
\hline $\mathrm{NAT}_{1}$ & 20.6 & 20.1 & $20.3 \mathrm{c}$ & 80.7 & 81.3 & $81.0 \mathrm{a}$ \\
\hline $\mathrm{NAT}_{2}$ & 22.3 & 21.4 & $21.8 \mathrm{~b}$ & 78.9 & 79.9 & $79.4 \mathrm{~b}$ \\
\hline $\mathrm{NAT}_{3}$ & 22.9 & 23.2 & $23.0 \mathrm{a}$ & 78.5 & 77.9 & $78.2 \mathrm{c}$ \\
\hline $\mathrm{NAT}_{4}$ & 23.2 & 22.7 & $22.9 \mathrm{a}$ & 78.0 & 78.5 & $78.2 \mathrm{c}$ \\
\hline $\operatorname{LSD}(0.05)$ & & & 0.6 & & & 0.8 \\
\hline \multicolumn{7}{|l|}{ Varieties } \\
\hline Pakhtunkhwa-2015 & 22.2 & 21.8 & 22.0 & 79.1 & 79.4 & 79.3 \\
\hline DN-84 & 22.2 & 21.6 & 21.9 & 79.0 & 79.7 & 79.3 \\
\hline Pirsabak-2015 & 22.3 & 21.9 & 22.1 & 78.9 & 78.9 & 78.9 \\
\hline $\operatorname{LSD}(0.05)$ & & & Ns & & & Ns \\
\hline Years means & 22.2 & 21.8 & Ns & 79.0 & 79.3 & Ns \\
\hline \multicolumn{7}{|l|}{ Interactions } \\
\hline NAR $x$ NAT & ns & ns & $* *$ & Ns & ns & ** \\
\hline NAR x V & $* *$ & ns & Ns & ** & $\mathrm{ns}$ & Ns \\
\hline NAT $x$ V & ns & ns & Ns & Ns & ns & Ns \\
\hline NAR $x$ NAT $x$ V & * & ns & Ns & * & $\mathrm{ns}$ & Ns \\
\hline
\end{tabular}

NAT $1=100 \%$ at sowing; NAT2 $=50 \%$ at sowing $(0$ DAS) $\& 50 \%$ at tillering $(70$ DAS); NAT3 $=25 \%$ at sowing $(0$ DAS), $50 \%$ at tillering (70 DAS) \& $25 \%$ at booting stage ( 100 DAS); NAT4 $=25 \%$ at sowing ( 0 DAS), $25 \%$ at tillering $(70$ DAS) \& $50 \%$ at booting stage (100 DAS). Means followed by different letter within a category of a treatments are statistically different from each other using least significant difference $(\mathrm{LSD})$ test $(\mathrm{p}<0.05)$.

and narrow down at $160 \mathrm{~kg} \mathrm{ha}^{-1}$. DGC was reported the highest with no changes for $\mathrm{NAT}_{3}$ and $\mathrm{NAT}_{4}$ at $140 \mathrm{~kg} \mathrm{ha}^{-1}$, clearly lower value for $\mathrm{NAT}_{2}$ followed by $\mathrm{NAT}_{1}$.

Amylose (\%): Grain amylose content (GAC) as influenced by NAR, NAT and varieties is shown in Table 4. Statistical analysis of data revealed that NAR and NAT had significant effect on GAC with non-significant changes in varieties. Averaged across NAT and varieties, maximum GAC reported at NAR $140 \mathrm{~kg} \mathrm{ha}^{-1}$ which was non-significant $(\mathrm{p}<0.05)$ with $160 \mathrm{~kg} \mathrm{ha}^{-1}$, followed by 120 and $100 \mathrm{~kg} \mathrm{ha}^{-1}$. Lowest GAC was recorded in the control treatment. When averaged across NAR and varieties, the maximum GAC was observed in three splits (i.e., $\mathrm{NAT}_{4}$ and $\mathrm{NAT}_{3}$ ), followed by two splits $\left(\mathrm{NAT}_{2}\right.$ ) and lowest under the $\mathrm{NAT}_{1}$. For interaction, NAR $\mathrm{x}$ NAT showed significant effect in GAC (Fig. 9). As observed GAC showed increments with increasing NAR with different fashion particularly for splits application at any given NAR. The GAC showed almost same readings for NAT at control with slight changes at NAR 100. Thereafter, NAR increased from 100 to $120 \mathrm{~kg} \mathrm{ha}^{-1}$, differences in GAC expands with highest at 140 and $160 \mathrm{~kg} \mathrm{ha}^{-1}$ where $\mathrm{NAT}_{4}$ was markedly dominate $\mathrm{NAT}_{3}$, followed by $\mathrm{NAT}_{2}$ and lowest by $\mathrm{NAT}_{1}$.

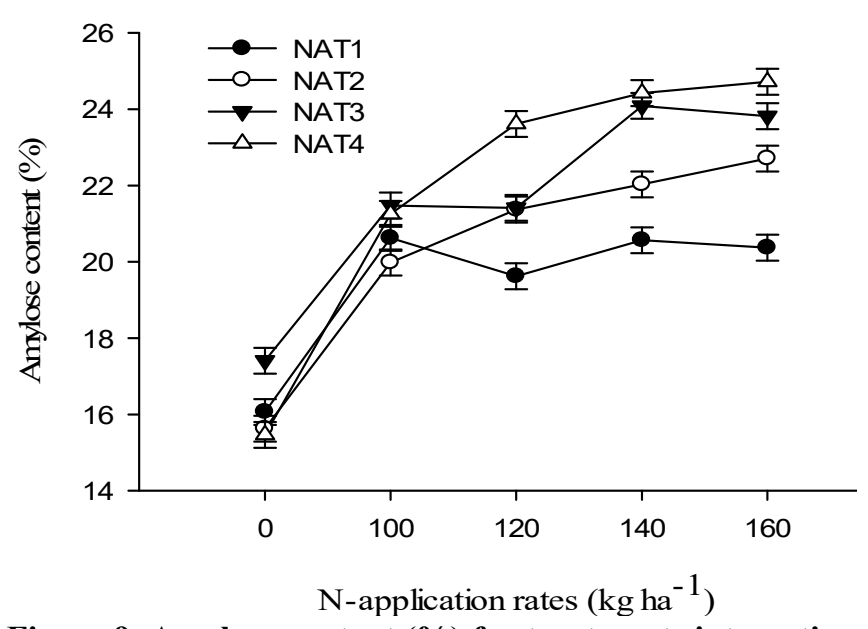

Figure 9. Amylose content (\%) for treatments interaction [N-application rates (NAR) $\mathrm{x}$-application timings].

Amylopectin (\%): Grain amylopectin (GAP) affected $(\mathrm{p}<0.05)$ by NAR, NAT and varieties (Table 4$)$. Averaged 
across NAT and varieties, NAR differed $(\mathrm{p}<0.05)$ in GAP, with highest in control, followed by $100 \mathrm{~kg} \mathrm{~N} \mathrm{ha}^{-1}$ which did not differ from $120 \mathrm{~kg} \mathrm{ha}^{-1}$. The lowest GAP was observed NAR $140 \mathrm{~kg} \mathrm{ha}^{-1}$ which was similar with NAR $160 \mathrm{~kg} \mathrm{ha}^{-1}$. Averaged across NAR and varieties, highest GAP was recorded in single application $\left(\mathrm{NAT}_{1}\right)$, followed by two splits $\left(\mathrm{NAT}_{2}\right)$ and subsequently three splits $\left(\mathrm{NAT}_{3}\right.$ and $\left.\mathrm{NAT}_{4}\right)$. Varieties were non-significant for GAP. Interaction (NAR $x$ NAT) was significant for GAP with a decrease $(p<0.05)$ by increasing NAR with highest for control, followed by 100 and lowest at $140 \mathrm{~kg} \mathrm{ha}^{-1}$ which did not differ from NAR $160 \mathrm{~kg}$ ha $^{-1}$ (Fig. 10). The GAP was almost same under NAR at control and markedly differs with highest for $\mathrm{NAT}_{1}$, followed by $\mathrm{NAT}_{2}$ and $\mathrm{NAT}_{3}$ with clear changes at NAR 140 and 160 $\mathrm{kg} \mathrm{ha}^{-1}$.

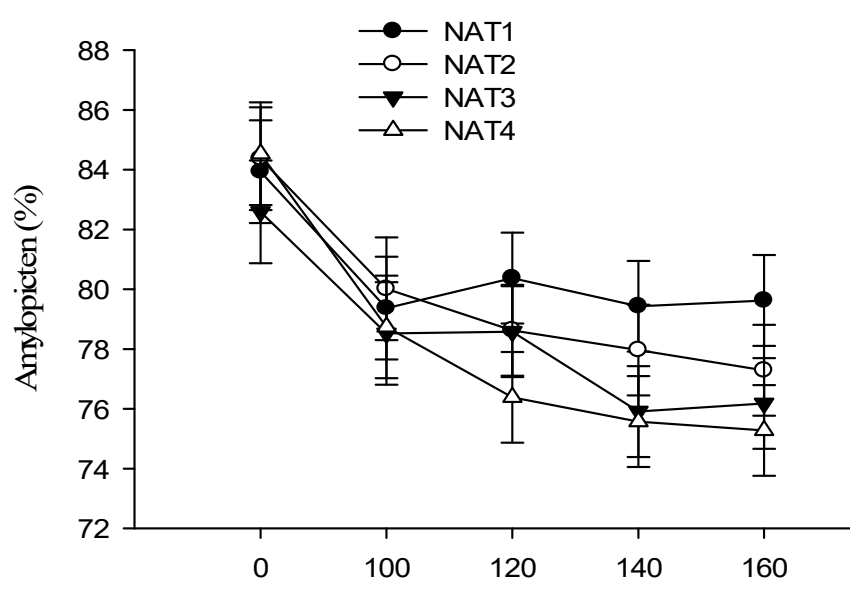

$\mathrm{N}$-application rates $\left(\mathrm{kg} \mathrm{ha}^{-1}\right)$

Figure 10. Amylopectin content (\%) for treatments interaction [N-application rates (NAR) $\times \mathrm{N}$ application timings].

\section{DISCUSSION}

The efficiency of nutrients up take by the plant depends on various biotic and abiotic factors. Among the abiotic factors, rainfall is considered as one of the major factors influencing $\mathrm{N}$ loss and its availability to crop. Significant loss in yield is observed when rain occurs during critical growth stages of the crop. Especially, during anthesis where crop is more sensitive to abiotic stresses and cause severe reduction in yield and quality. Considering the strong relation of $\mathrm{N}$ leaching and volatilization with proper nitrogen management this study was designed to evaluate $\mathrm{N}$-application rates and $\mathrm{N}$ application timings for different wheat varieties. The present study was evaluated on spring wheat under NAR and NAT to observe the impact of $\mathrm{N}$ on grain yield and quality. Nitrogen application rate and timing have shown significant impacts on grain yield and grain $\mathrm{N}$-content as compared to the control treatment (Ierna et al., 2015). Higher grain yield and grain $\mathrm{N}$ was observed with the application of $140 \mathrm{~kg} \mathrm{~N}^{-1}$ given in three splits. Nitrogen fertilizer is a critical constituent of plants, its availability at critical growth stage (vegetative and reproductive) may also improve photosynthetic activity by improving chlorophyll content, hence better partitioning of assimilates to grains which increases final grain yield. Belete et al. (2018) also depicted similar results where they showed increasing $\mathrm{N}$ rate to a certain level in the wheat crop has improved the final yield. Nitrogen use efficiency was significantly decreased with each increment in NAR from 100 to $160 \mathrm{~kg} \mathrm{ha}^{-1}$. Similar results were reported by (Caviglia and Sadras, 2001) that increment in nitrogen rate decreased nitrogen use efficiency. Split application is a useful strategy for increasing NUE and was observed higher in three splits application ( $\mathrm{NAT}_{3}$ and $\mathrm{NAT}_{4}$ ). Our results are in conformity with Jan et al. (2010) that split application has increased NUE. The genetic make-up of varieties also plays a key role in quality traits especially NUE (Wang et al., 2011; Fageria et al., 2005). Varieties might significantly differ for NUE because of its genetic potential (Haile et al., 2012).

Nitrogen availability in soil is compulsory for better crop production (Cui et al., 2008). Crude protein contents increased with $\mathrm{N}$ increments with maximum for higher NAR. Concurrently, treatment without $\mathrm{N}$-application resulted in minimum crude protein. Grain protein content is considered as key factor for quality which is ensured by optimum $\mathrm{N}$ rates and proper application timing (Fageria et al., 2005). Nitrogen is building blocks of protein and optimum crude protein is only possible in grain when there is proper availability of soil nitrogen during different stages of crop growth. For harvesting maximum grain crude protein, adequate amount of $\mathrm{N}$ at proper growth stage is important (Anthony et al., 2003; Ooro et al., 2011) stated that $\mathrm{N}$-application rates and timings influence baking quality of wheat. In addition, they reported a significant improvement in grain protein with an increment in N-rates. Optimum $\mathrm{N}$ in conjunction with its proper application methods has maximized wheat productivity (Sohail et al., 2013). Similarly, three splits of N-application resulted higher $\mathrm{N}$-content and ultimately maximum grain protein. It was observed that for seed yield, crude protein, and NUE, split $\mathrm{N}$ fertilization was much more effective than applying total nitrogen or in two splits (Mohammed et al., 2013). Grain protein content varies for varieties due to variation in uptake potential and genetic makeup (Kanu et al., 2017. Variety Pirsabak-15 produced maximum protein content followed by DN-84 while, the minimum protein content was observed in Pakhtunkhwa-15.

The considerable variations in both growing seasons might cause changes in wet gluten content (Vrkoc et al., 1995). Nitrogen application rate might affect wheat wet gluten content because nitrogen is building block of protein and essential component of plant growth and development (Qadeer et al., 2019). Similar results were reported by Ottman et al. (2000) where increment in N-rate resulted in better grain 
quality attributes, especially gluten. The split $\mathrm{N}$-application is therefore essential for the optimum uptake and utilization of the plants and hence are responsible for better grain quality (Alcoz et al., 1993). Several studies showed that N split application enhanced wheat protein concentrations and thereby reducing overall $\mathrm{N}$-rate and limits $\mathrm{N}$-losses in rhizosphere (Ayoub et al., 1994). In the current study, variation among the gluten content for varieties might be due to the genetic potential of cultivars (Hafid et al., 1996). Wheat dry gluten content varied significantly for both growing seasons. This variation in dry gluten of wheat over the season is because of the considerable variation in the weather parameters i.e. the distribution of rainfall in crop life cycle. Our results supported the publish findings (Vrokoc et al., 1995; Garrido-Lestache et al., 2005). They reported variations in gluten content through fluctuation in weather. Similarly, nitrogen application rate also affected dry gluten contents of wheat because nitrogen is one of the key nutrients and building block of the protein thereby responsible for plant growth and development (Qadeer et al., 2019; Johansson et al., 2004). Likewise, Ottman et al. (2000) reported that increment in N-rate result in better grain quality attributes especially dry gluten. The split $\mathrm{N}$-application is, therefore, essential for the optimum uptake and utilization of plants and hence are responsible for better grain quality (Alcoz et al., 1993; Xue et al., 2016). Several studies showed that split application of the nitrogen enhance the protein concentrations of wheat and thereby reducing overall N-rate and limits Nlosses in rhizosphere (Dinnes et al., 2002).

Wheat starch composition is an important quality trait from the prospective of food technologists due to its importance in industrial applications (Sestili et al., 2010). Currently, researchers are focusing on the production of starch with high amylose content because such starch offers high resistance to shear thinning if used as a thickening agent in other foods. The climatic factors affecting amylose contents of wheat is well documented by Buresova et al. (2010). Maximum amylose contents were observed for higher nitrogen rate application and decrease in N-rate from optimum decrease the starch formation in wheat (Singh et al., 2011). Split application of nitrogen enhances the nitrogen uptake and physiological efficiency and is enhanced by the split application of nitrogen (Amiri et al., 2014). Hence, results in formation of starches, with a higher amylose contents in wheat boosting grain quality (Maqsood et al., 2013). The variation in the starch contents of wheat cultivars is due to the cultivar's capability to translocate the available nutrients to starches thereby enhancing final grain quality (Massaux et al., 2008). Wheat grain comprised of various components. Of them amylopectin structure is of multiple clusters and each cluster includes various chains. These chains vary through length and position (Beroft et al., 2012). Weather conditions affect grain compositions of wheat by manipulating the soil nutrients availability (Buresova et al., 2010). Nitrogen application at higher rate resulted in less amylopectin whereas decrease in N-rate improves the amylopectin contents (Wang et al., 2008). Split application of nitrogen enhances the nitrogen uptake and physiological efficiency resulting in higher amylose contents and ultimately decreasing the amylopectin composition in grains (Gous et al., 2015). The efficient $\mathrm{N}$ uptake by plants due to split $\mathrm{N}$-application resulted in higher amylose and less amylopectin in wheat starches, boosting the grain quality (Xiong et al., 2008). In conclusion, grain quality parameters i.e., grain $\mathrm{N}$, protein content, amylose, wet and dry gluten were positive affected by $140 \mathrm{~kg}$ $\mathrm{N} \mathrm{ha}^{-1}$ under three splits (i.e. $25 \% \mathrm{~N}$ at sowing, $50 \% \mathrm{~N}$ at tillering and $25 \% \mathrm{~N}$ at, booting stage). The three splits $\mathrm{N}$ application could be a useful strategy to overcome $\mathrm{N}$ losses, reduce cost of production and ensure grain quality in wheat crop as compared to the traditional two splits $\mathrm{N}$ application technique.

Conclusions: From the study, it is concluded that existing recommended two-splits $\mathrm{N}$-application timings for wheat crop is no more effective under flood water irrigation system and subsequently changes expected to be observed in the rainfall pattern with climate change in Pakistan. The three splits application i.e. $\left(\mathrm{NAT}_{3}\right.$ or $\left.\mathrm{NAT}_{4}\right)$ at seedbed preparation, tillering and booting either $25,50,25$ or $25,25,50$ ratios, respectively is more effective to be applied as per recommended rate (i.e., $140 \mathrm{~kg} \mathrm{~N} \mathrm{ha}^{-1}$ ) to improve grain yield and quality for good backing flour. Cultivars do play an important role in $\mathrm{N}$-uptake, hence a recommended variety has to be selected for better $\mathrm{N}$ use efficiency for the cropping system.

Acknowledgement: The authors greatly acknowledged the financial support of Higher Education Commission, Islamabad extended under grant No 20-5178 as NRPU project to complete this work without any financial hurdles. It was a great support of HEC to scholar financially poor accomplishing the research task for higher studies in Universities.

Conflicts of Interest: The authors declare no conflict of interest.

\section{REFERENCES}

Aczel, M.R. 2019. What is the nitrogen cycle and why is it key to life? Centre for Environmental Policy, Imperial College London, UK.

Adeyemi, O., R. Keshavarz-Afshar, E. Jahanzad, M.L. Battaglia, Y. Luo, and A. Sadeghpour. 2020. Effect of wheat cover crop and split nitrogen application on corn yield and nitrogen use efficiency. Agron. J. 10:592.

Adhikari, L., A. Hussain, and G. Rasul. 2020. Tapping the potential of neglected and underutilized food crops for 
sustainable nutrition security in the mountains of Pakistan and Nepal. Sustainability. 22:5045-5075.

Agegnehu, G., A.M. Bass, P.N. Nelson, and M.I. Bird. 2016. Benefits of biochar, compost and biochar-compost for soil quality, maize yield and greenhouse gas emissions in a tropical agricultural soil. Sci. Total Environ. 543:295306.

Alcoz, M.M., F.M. Hons, and V.A. Haby. 1993. Nitrogen fertilization timing effect on wheat production, nitrogen uptake efficiency, and residual soil nitrogen. Agron. J. 85:1198-1203.

Amiri, M., M. Mojaddam, A. Shokouhfar, and N. Bakhtiarinejad. 2014. The effect of different levels and time of nitrogen application on grain yield, some physiological traits and nitrogen use efficiency in grain sorghum. Indian J. Fundam. Appl. Life Sci. 4:223-227.

Anthony, G., B. Woodard, and J. Hoard. 2003. Foliar N application timing influence on grain yield and protein concentration of hard red winter and spring wheat. Agron. J. 95:335-338.

Asim, M., M. Akmal and R. A. Khattak. 2013. Maize response to yield and yield traits with different nitrogen and density under climate variability. J. Plant Nutrition. 36:179-191.

Ayoub, M. S. Guertin, J. Fregeau-Reid, and D.L. Smith, 1994. Nitrogen fertilizer effect on breadmaking quality of hard red spring wheat in eastern Canada. Crop Sci.34:13461352.

Barak, S.; D. Mudgil, and B.S. Khatkar. 2013. Relationship of gliadin and glutenin proteins with dough rheology, flour pasting and bread making performance of wheat varieties. LWT-Food Sci. Technol. 51:211-217.

Basit, A., M.I. Gul, A.K. Jaffar and N. Ahmad. 2005. Studies of Nitrogen use Efficiency in Wheat (Triticum aestivum L.) by split application at different growth (year)? stages. J.App.Em. Sci.1:39-42.

Belete, F., N. Dechassa, A. Molla, and T. Tana. 2018. Effect of nitrogen fertilizer rates on grain yield and nitrogen uptake and use efficiency of bread wheat (Triticum aestivum L.) varieties on the vertisols of central highlands of Ethiopia. Agric. Food Security. 7:1-12

Bertoft, E. K. Koch, and P. Åman. 2012. Building block organization of clusters in amylopectin from different structural types. Int. J. Biol. Macromol. 50:1212-1223.

Blumenthal, J. M. D.D Baltensperger, K.G. Cassman, S.C. Mason and A.D. Pavlista. 2008. Importance and effect of nitrogen on crop quality and health. In Nitrogen in the Environment.. Academic Press. Elsevier Inc. pp. 51-70.

Box, G. and S. Jones. 1992. Split-plot designs for robust product experimentation. J. Appl. Stat. 19:3-26.

Brown, B.D. and S. Petrie. 2006. Irrigated hard winter wheat response to fall, spring, and late season applied nitrogen. Field Crop Res. 96:260-268.
Burešová, I. I. Sedláčková, O. Faměra, and J. Lipavský. 2010. Effect of growing conditions on starch and protein content in triticale grain and amylose content in starch. Plant, Soil and Environment.56:99-104.

Burhan, K.A.R.A. 2010. Influence of late-season nitrogen application on grain yield, nitrogen use efficiency and protein content of wheat under Isparta ecological conditions. Turk. J. Field Crops. 15:1-6.

Cappelli, A. L. Bettaccini, and E. Cini. 2020. The kneading process: A systematic review of the effects on dough rheology and resulting bread characteristics, including improvement strategies. Trends Food Sci. Technol.104:91-101.

Caviglia, O.P. and V.O. Sadras. 2001. Effect of nitrogen supply on crop conductance, water-and radiation-use efficiency of wheat. Field Crop Res. 69:259-266.

Chaturvedi, I. 2005. Effect of nitrogen fertilizers on growth, yield and quality of hybrid rice (Oryza sativa). J. Cent. Eur. Agric. 6:611-618.

Cormier, F. J. Foulkes, B. Hirel, D. Gouache, Y. MoënneLoccoz, and J. Le-Gouis. 2016. Breeding for increased nitrogen-use efficiency: a review for wheat (T. aestivum L.). Plant Breeding. 135:255-278.

Cui, Z., F. Zhang, Y. Miao, Q. Sun, F. Li, X. Chen, J. Li, Y Ye, Z. Yang, Q. Zhang, and C. Liu. 2008. Soil nitrate-N levels required for high yield maize production in the North China Plain. Nutr. Cycl. Agroecosys.82:187-196.

Da-Moraes, L.B.D. J.D. Freo, B. Biduski, M.C. Elias, and L.C. Gutkoski. 2013. Effects of rate, time and splitting of nitrogen fertilization on the technological quality of wheat. J. Food Sci. Eng. 3:1-9.

Delloye, C. M. Weiss, and P. Defourny. 2018. Retrieval of the canopy chlorophyll content from Sentinel-2 spectral bands to estimate nitrogen uptake in intensive winter wheat cropping systems. Remote Sensing Environ. 216:245-261.

Dinnes, D.L. D.L. Karlen, D.B. Jaynes, T.C. Kaspar, J.L. Hatfield, T.S. Colvin, and C.A. Cambardella. 2002. Nitrogen management strategies to reduce nitrate leaching in tile-drained Midwestern soils. Agron. J. 94:153-171.

Elli, L.F. Branchi,C. Tomba, D.Villalta,L. Norsa,F. Ferretti and M.T. Bardella. 2015. Diagnosis of gluten related disorders: Celiac disease, wheat allergy and non-celiac gluten sensitivity. World J.Gastroentero. 21:7110.

Fageria, N.K. and A.S. Nascente. 2014. Management of soil acidity of South American soils for sustainable crop production. Adv. Agron. 128:221-275.

Fageria, N.K. and V.C. Baligar. 2005. Enhancing nitrogen use efficiency in crop plants. Adv. Agron.88:97-185.

Fuertes-Mendizábal, T. A. Aizpurua, M.B. González-Moro, and J.M. Estavillo. 2010. Improving wheat breadmaking quality by splitting the $\mathrm{N}$ fertilizer rate. Eur. J. Agron. 33: 52-61. 
Garrido-Lestache, E. R.J. López-Bellido, andL. LópezBellido. 2005. Durum wheat quality under Mediterranean conditions as affected by $\mathrm{N}$ rate, timing and splitting, $\mathrm{N}$ form and S fertilization. Eur. J. Agron. 23:265-278.

Geleta, B. M. Atak, P.S. Baenziger, L.A. Nelson, D.D. Baltenesperger, K.M. Eskridge, M.J. Shipman, and D.R. Shelton. 2002. Seeding rate and genotype effect on agronomic performance and end-use quality of winter wheat. Crop Sci. 42:827-832.

Gous, P.W. F. Warren, O.W. Mo, R.G. Gilbert, and G.P. Fox. 2015. The effects of variable nitrogen application on barley starch structure under drought stress. J. I. Brewing. 121: 502-509.

Hafid, R. M. El-Mourid, and K. Samir. 1996. Characterization of cultivars of wheat, barley and triticale under different moisture conditions in the field and using a crop model. Al-Awamia.93:7-25.

Haile, D., D. Nigussie, and A. Ayana. 2012. Nitrogen use efficiency of bread wheat: Effects of nitrogen rate and time of application. J. Soil Sci. Plant Nutr.12:389-410.

Hanif, M. and J. Ali. 2014. Climate scenarios 2011-2040 districts Haripur, Swabi, Attock and Chakwal, Pakistan. Report Climate Change Centre, the University of Agric. Peshawar.

Herrera, J.M., G. Rubio, L.L. Häner, J.A. Delgado, C.A. Lucho-Constantino, S. Islas-Valdez, and D. Pellet. Emerging and established technologies to increase nitrogen use efficiency of cereals. Agron. 6:2-25.

Hirel, B., T. Tétu, P.J. Lea, and F. Dubois. 2011. Improving nitrogen use efficiency in crops for sustainable agriculture. Sustainability. 3:1452-1485.

Ierna, A., G. M. Lombardo and G. Mauromicale. 2015. Yield, Nitrogen Use efficiency and grain quality in durum wheat as affected by nitrogen fertilization under a Mediterranean environment. Cambridge Uni. Press. Pp.1-16.

Jan, M.T., J.M. Khan, A. Khan, M. Arif, M. Shafi, M. and N. Nullah. 2010. Wheat nitrogen indices response to nitrogen source and application time. Pak. J. Bot. 42:4267-4279.

Johansson, E., M.L. Prieto-Linde, and G. Svensson. 2004. Influence of nitrogen application rate and timing on grain protein composition and gluten strength in Swedish wheat cultivars. J. Plant Nutr. Soil Sci. 167:345-350.

Jones C., B.D. Brown, R. Engel, D. Horneck, and K. OlsonRutz. 2013. Nitrogen fertilizer volatilization. Montana State University Extension, EB0208 \& EB0209.

Kanu, A.S., U. Ashraf, Z. Mo, I. Fuseini, L.R. Mansaray, M. Duan, S. Pan, and X. Tang.2017. Cadmium uptake and distribution in fragrant rice genotypes and related consequences on yield and grain quality traits. J. Chem. Pages 9.

Kozin, R., L. Kuznetsova, N. Hulyanytska, and I. Mossokovska. 2019. Determination of Nitrogen Content in the Slags of $\mathrm{CaO}-\mathrm{A} 12 \mathrm{O} 3$ System by Kjeldahl Method. Metrol. Instruments. 3:55-60.

Leghari, S.J., N.A. Wahocho, G.M. Laghari, A. H. Laghari, G. M. Bhabhan, K. H. Talpur, T.A. Bhutto, S.A. Wahocho, and A.A. Lashari. 2016. Role of nitrogen for plant growth and development: A review. Advances Environ. Biol. 10:209-219.

Maqsood, M., M.A. Shehzad, S.N.A. Ali, and M. Iqbal. 2013. Rice cultures and nitrogen rate effects on yield and quality of rice (Oryza sativa L.). Turk. J. Agric. For. 37: 665-673.

Massaux, C., M. Sindic, J. Lenartz, G. Sinnaeve, B. Bodson, A. Falisse, P. Dardenne, and C. Deroanne. 2008. Variations in physicochemical and functional properties of starches extracted from European soft wheat (Triticum aestivum L.): The importance to preserve the varietal identity. Carbohyd. Polym. 71:32-41.

Medford, A.J., and M.C. Hatzell 2017. Photon-driven nitrogen fixation: current progress, thermodynamic considerations, and future outlook. Acs Catalysis. 7:2624-2643.

Mohammed, Y.A., J. Kelly, B.K. Chim, E. Rutto, K. Waldschmidt, J. Mullock, G. Torres, K.G. Desta, and W. Raun. Nitrogen fertilizer management for improved grain quality and yield in winter wheat in Oklahoma. J. Plant Nutr. 36:749-761.

Nakamura, S., H. Yamaguchi, Y. Benitani, and K.I. Ohtsubo. 2020. Development of a novel formula for estimating the amylose content of starch using japonica milled rice flours based on the iodine absorption curve. Biosci. Biotech. Biochem. 84:2347-2359.

Ni, K., A. Pacholski, and H. Kage. 2014. Ammonia volatilization after application of urea to winter wheat over 3 years affected by novel urease and nitrification inhibitors. Agric. Ecosy. Environ. 197:184-194.

Ooro, P.A., J.N. Malinga, D.G. Tanner, and T.S. Payne. 2011. Implication of rate and time of nitrogen application on wheat (Triticum aestivum. L.) yield and quality in Kenya. J. Anim. Plant Sci. 9:1141-1146.

Ottman, M.J., T.A. Doerge, and E.C. Martin. 2000. Durum grain quality as affected by nitrogen fertilization near anthesis and irrigation during grain fill. Agron. J. 92:1035-1041.

Pfeifer, M., K.G. Kugler, S.R. Sandve, B. Zhan, H. Rudi, T.R. Hvidsten, K.F. Mayer, and O.A. Olsen. 2014. International wheat genome sequencing consortium, genome interplay in the grain transcriptome of hexaploid bread wheat. Science. 345:61-94.

Preece, C., A. Livarda, P.A. Christin, M. Wallace, G. Martin, M. Charles, G. Jones, M. Rees, and C.P. Osborne. 2017. How did the domestication of fertile crescent grain crops increase their yields? Functional ecology.312:387-397.

Qadeer, U., M. Ahmed, F.U. Hassan, and M. Akmal. 2019. Impact of nitrogen addition on physiological, crop total 
nitrogen, efficiencies and agronomic traits of the wheat crop under rainfed conditions. Sustainability.11:6486.

Sayaslan, A. P.A. Seib, and O.K. Chung. 2006. Wet-milling properties of waxy wheat flours by two laboratory methods. J. Food Eng.72:167-178.

Sestili, F., M. Janni, A. Doherty, E. Botticella, R. D'Ovidio, S. Masci, H.D. Jones, and D. Lafiandra. 2010. Increasing the amylose content of durum wheat through silencing of the SBEIIagenes. BMC Plant Biology.10:144.

Sher, A. 2019. Agronomic Biofortification of Wheat with Zinc and Iron under different nitrogen regimes. Doctoral dissertation submitted to Univ. Haripur. Pakistan.

Singh, N., N. Pal, G. Mahajan, S. Singh, and K. Shevkani. 2011. Rice grain and starch properties: Effects of nitrogen fertilizer application. Carbohyd. Polym. 86:219-225.

Sohail, M., I. Hussain, S.H. Abbas, M. Qamar, and M. Noman. 2013. Effect of split $\mathrm{N}$ fertilizer application on physio-agronomic traits of wheat (Triticum aestivum L.) under rainfed conditions. Pak. J. Agric. Res. 26:71-78.

Steel, R.G. and J.H. Torrie. 1986. Principles and procedures of statistics: a biometrical approach. McGraw-Hill, UK.

Taylor, J.K and C. Cihon. 2004. Statistical techniques for data analysis. CRC Press.

Vrkoc, F., M. Vach, and J. Skala. 1995. The effect of growing methods, sites and years on the nutrient content and baking quality of winter wheat grain. RostlinnaVyrobaUZPI, Czech Republic.

Wang, R.F., D.G. An, C.S. Hu, L.H. Li, Y.M. Zhang, Y.G. Jia and Y.P. Tong. 2011. Relationship between nitrogen uptake and use efficiency of winter wheat grown in the North China Plain. Crop Pasture Sci.62:504-514.

Wang, X., M. He, F. Li, Y. Liu, H. Zhang, and C. Liu, C. Coupling effects of irrigation and nitrogen fertilization on grain protein and starch quality of strong-gluten winter wheat. Front. Agric. China.2:274-280.

Xiong, F., W.A.N.G. Zhong, Y.J. Gu, C.H.E.N. Gang, and Z.H.O.U. Peng. 2008. Effects of nitrogen application time on caryopsis development and grain quality of rice variety Yangdao Rice Sci. 15:57-62.

Xue, C., A. Matros, H.P. Mock and K.H. Mühling. 2019. Protein composition and baking quality of wheat flour as affected by split nitrogen application. Front. Plant Sci. 10: 642 .

Xue, C., A. Rossmann, R. Schuster, P. Koehler, and K.H. Mühling. 2016. Split nitrogen application improves wheat baking quality by influencing protein composition rather than concentration. Front. Plant Sci. 7:738.

Zörb, C., C. Grover, D. Steinfurth, and K.H. Mühling. 2010. Quantitative proteome analysis of wheat gluten as influenced by $\mathrm{N}$ and S nutrition. Plant Soil. 327:225-234. 